\title{
Contrasts In The Locational Attractiveness Of The Southeast To New Manufacturers\#
}

\author{
Emil Malizia and Anthony Marimpietri*
}

\begin{abstract}
This research is based on a survey of manufacturers that made capital investments in North Carolina, South Carolina and Virginia between 1977 and 1981. It examines the locational preferences of executives that selected these states for new manufacturing establishments. The results show contrasts in the locational attractiveness of this area for different establishment characteristics. Compared to all new establishments, type of establishment (branch plant versus independent firm), establishment employment size, and the growth rate of the establishment's industry result in distinctively different profiles of executive locational preferences. When taken in combination, these characteristics further distinguish executive preferences.
\end{abstract}

\section{INDUSTRIAL LOCÁTION IN THE SOUTHEAST}

The features of a region and of a particular site that typically attract manufacturers have been documented in many industrial location studies (e.g., Czamanski, 1981, Moriarity, 1980, Schmenner, 1982, Carlton, 1979, Vaughan, 1977, Lonsdale and Seyler, 1979, Cromley and Leinbach, 1981, Lonsdale and Browning, 1971, Haren, 1974, Till, 1973, and Weinstein and Firestein, 1978). The importance of these features is known to vary across industries and establishment characteristics. The purpose of this paper is to analyze the ways in which establishment characteristics impinge upon the locational preferences of manufacturers initiating operations in the southeast.

Explanations of such variations in the spatial diffusion of industry which are based on product cycle theory have particular force in this region (Vernon, 1966, Thompson, 1968, Hymer, 1972, Barnet and Muller, 1974, pp. 129-133, Malizia and Reid, 1976, Erickson and Leinbach, 1979, Norton and Rees, 1979, and Hekman, 1980). In a recent analysis of manufacturing decentralization, Niles. Hansen summarizes the spatial filtering and 
product cycle argument. He concludes that "without denying that a great variety of situations exist with respect to industrial organization and manufacturing decentralization, the available evidence suggests that branch plants of existing corporations are the typical means by which [the spatialindustrial filtering process] is realized." (Hansen, 1979, pp. 5-6).

One would expect that the regional economic characteristics of the southeastern states would make them better locations for the manufacture of standardized products than for the creation of new products. First, there are good transportation networks and excellent access to major eastern, southern and midwestern markets from these states. Second, there is an attractive mix of labor. Sufficient skilled workers are available, but so is the critical supply of less skilled workers needed for standardized production processes. Third, there is a pro-business orientation and very limited unionization. Fourth, compared to other states, wages and land costs are low and the costs of other important inputs are competitive. Fifth, the states are much less urban than the national average, offering excellent sites and below average construction costs for large, capital-intensive manufacturing facilities.

Results of the survey data support these expectations. Of the 136 new establishments, new branch plants dominated the sample, accounting for $72 \%$ of the total. Of the branch plants, $57.5 \%$ were in industries growing at about the national average while another $14.2 \%$ fell well below the average national growth rate. Branch plants were also much larger than the average establishment in the sample. Comparing the number of branch plants to the total number of new establishments in each of the three employment size categories set up for sampling purposes, branch plants accounted for $65 \%$ of small manufacturers (under 50 employees), $81 \%$ of medium-sized manufacturers (from 50 to 249 employees), and $92 \%$ of large manufacturers (over 249 employees).

Previous studies suggest that industrial location decisions are sequential (Moriarity, 1980 and Schmenner, 1982). First, the decision to create new capacity is made. Next, executives decide on the appropriate region or general area and subsequently select the particular community or site for the facility. This research focused on the regional and site selection process. Access, input availability and cost factors impinge heavily on the selection of regional location while they are less important in choosing a particular community or site. Conversely, community quality of life factors and state or local government efforts to support industrial development come into play primarily at the later stages of the decision making process, after the general region or area has been determined.

With respect to industrial recruitment efforts, during the past decade as population and economic activity have shifted from northern, especially metropolitan, areas to southern and nonmetropolitan areas, states and local governments have escalated their competition for job-creating investments, particularly for the branch plants of major national and transnational firms (Lonsdale and Seyler, 1979, Weinstein and Firestein, 1978 and Haren, 1974). The southeastern states have been active industrial recruiters, and, judging from surveys of executive opinion (for exam- 
ple, the recent Alexander Grant survey), they have been among the most successful. Yet industrial recruitment strategies are being refined in this region, in an attempt to increase their probability of success and to attract industrial prospects more selectively.

The survey asked executives to rate a broad set of locational factors: basic economic factors referred to as access, input availability and cost factors, and community quality of life factors. Their opinions were also sought on a typical array of government activities that are thought to encourage (or discourage) industrial development, including state financial incentives, environmental regulations and availability of infrastructure. The 31 locational variables, grouped into the three categories are shown in Table 1.

The survey was sent to a large random sample of establishments stratified by employment size. The executives surveyed had been involved with manufacturing facility start-ups, expansions or relocations that occurred in North Carolina, South Carolina and Virginia between January 1, 1977 and March 31, 1981. Over 70\% of these executives responded to the survey. Focusing on the 136 new establishments from the total of 204 establishments, initial research examined the locational profile for all new establishments (Malizia, 1982). This research concentrated on contrasts in the responses of executives from manufacturing concerns with different characteristics. Six pertinent characteristics are given for the new establishments in Table 2.

\section{TABLE 1}

Industrial Location Variables*

\begin{tabular}{|c|c|c|}
\hline $\begin{array}{c}\text { Access/Input } \\
\text { Availability \& Cost }\end{array}$ & $\begin{array}{c}\text { Community Quality } \\
\text { Of Life }\end{array}$ & $\begin{array}{l}\text { State/Local Government } \\
\text { Support For } \\
\text { Industrial Development }\end{array}$ \\
\hline $\begin{array}{l}\text { Labor productivity } \\
\text { Skilled labor supply } \\
\text { Unskilled labor supply } \\
\text { Wage rates } \\
\text { State/local industrial } \\
\quad \text { climate } \\
\text { Electricity availability/ } \\
\text { cost } \\
\text { Fuel availability/cost } \\
\text { Transportation } \\
\text { Proximity to markets } \\
\text { Proximity to suppliers/ } \\
\text { business services } \\
\text { Land availability/room for } \\
\text { expansion } \\
\text { Cost of land and construction }\end{array}$ & $\begin{array}{l}\text { Housing } \\
\text { Educational system } \\
\text { Recreational opportunities } \\
\text { Cultural resources } \\
\text { Entertainment } \\
\text { Personal taxes } \\
\text { Cost of living } \\
\text { Physical quality of air and } \\
\text { water resources } \\
\text { Aesthetic quality of } \\
\text { natural landscape } \\
\text { (scenery) } \\
\text { Open space } \\
\text { Transportation (local } \\
\text { traffic conditions/public } \\
\text { transportation) } \\
\text { Climate }\end{array}$ & $\begin{array}{l}\text { Availability of technical } \\
\text { training programs } \\
\text { Business taxation } \\
\text { State financial incentives } \\
\text { Water supply } \\
\text { Public wastewater } \\
\text { treatment capacity } \\
\text { Solid/hazardous waste } \\
\text { disposal facilities } \\
\text { State/local environmental } \\
\text { regulations and permit } \\
\text { processing }\end{array}$ \\
\hline
\end{tabular}

*The author will make a copy of the survey instrument available on request. 
TABLE 2

Manufacturing Establishment Characteristics

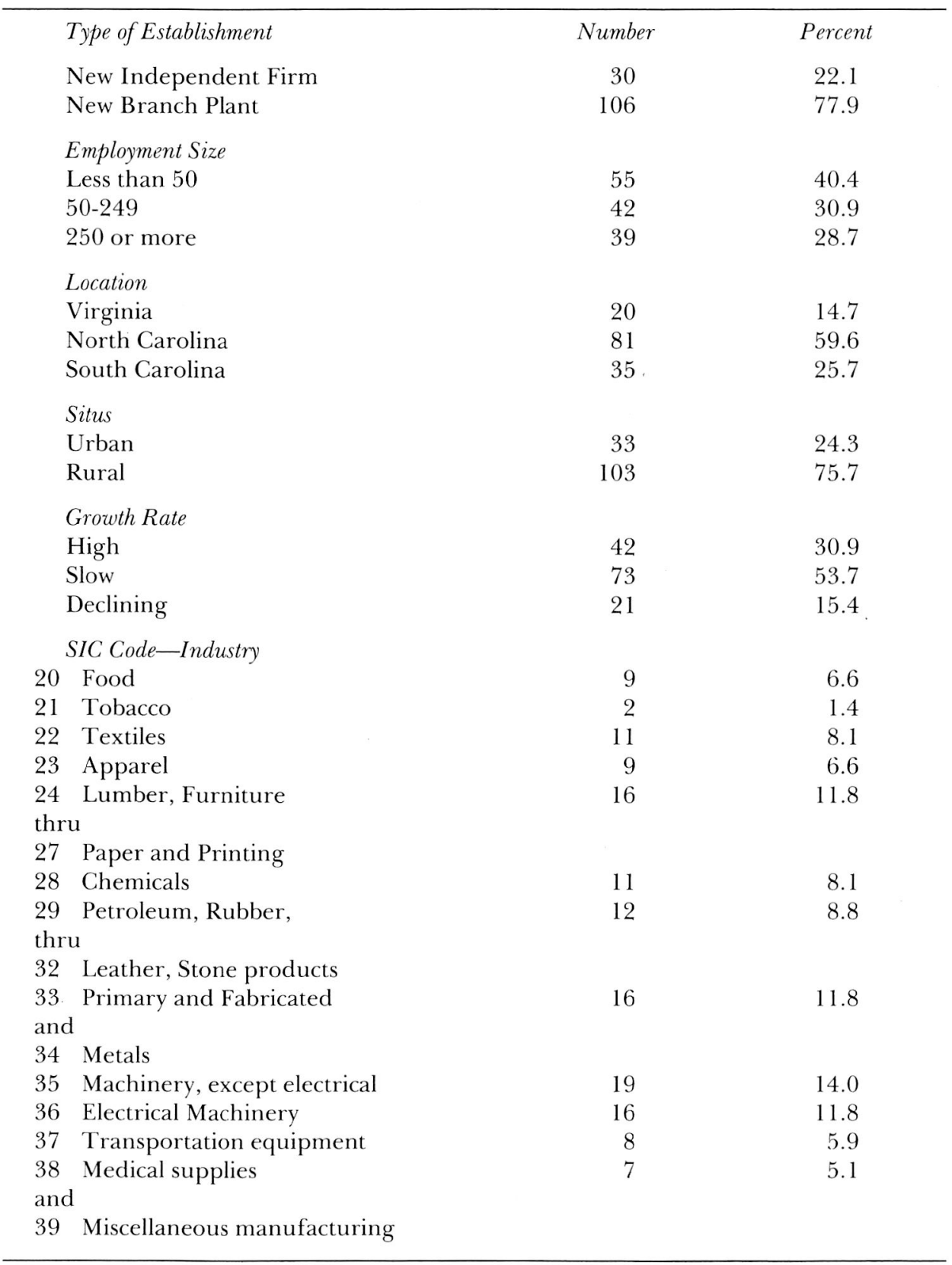




\section{MULTIVARIATE ANALYSES}

Business executives were asked to rate the importance of the 31 locational variables listed in Table 1 along a five-interval, 'Likert' scale (1-not important, 2-slightly important, 3-moderately important, 4-very important, and 5-extremely important). In addition to the establishment type (independent firm or branch plant), three employment size categories used for sampling purposes (under 50, 50-249 and over 249) and three growth rate categories ${ }^{1}$ proved to be the most useful independent treatments for the analysis.

The first step was to examine the interrelationships among the locational variables using factor analysis. The factor analysis summarized the 31 locational variables to 10 factor dimensions, explaining $75 \%$ of the variation in the original variables. From a varimax rotation, seven group factors and three specific factors were derived. Each rotated factor had an eigen value of greater than 1.0 which increased with the number of variables loading heavily on that factor.

The next step tested for meaningful differences among the executives' preferences for each of the establishment characteristics. Using the ten rotated factors, discriminant analyses were conducted on establishment type, employment size, growth rate, state of location (N.C., S.C., or Va.) and rural or urban situs. Only the first three characteristics had distinguishable categories. There were very few classification errors for the three employment size categories, the four growth rate categories and for branch plants. For independent firms, 53\% were correctly classified.

The third step measured the overall association between the ten factors and the three important establishment characteristics (type, size and growth rate). The results of a canonical correlation analysis yielded six sets of linear combinations of the factors and establishment characteristics that explained much of the variation. Two of the six dimension correlations were statistically significant.

The fourth step identified the most important independent and interaction effects of the three characteristics on the ten factors, using a general linear model of the form:

$$
(F 1, F 2, \ldots F 10)=f\left(T, E, G, T^{*} E, E^{*} G, T^{*} G, T^{*} E^{*} G\right)
$$

where:

$$
\begin{aligned}
\text { F1-F10 } & =\text { Rotated factors } \\
\mathrm{T} & =\text { establishment type; } \\
\mathrm{E} & =\text { employment size; and } \\
\mathrm{G} & =\text { growth rate }
\end{aligned}
$$

Employment size and growth rate were significant beyond the $1 \%$ level, while the interaction of all three treatments was significant at the $3 \%$ level. 
TABLF 3

Identified Factors And Factor Loading*

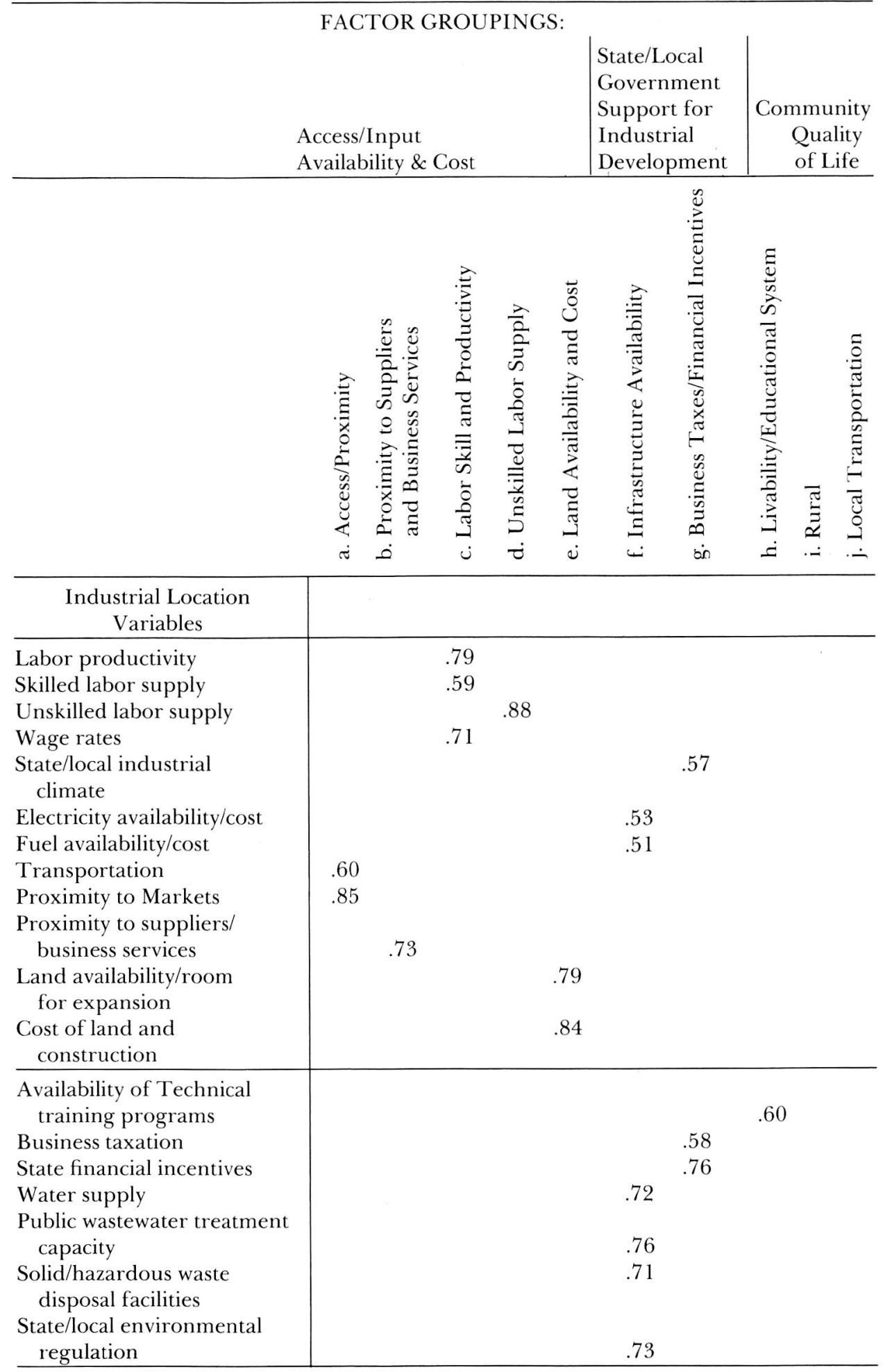


TABLE 3

Identified Factors And Factor Loading*

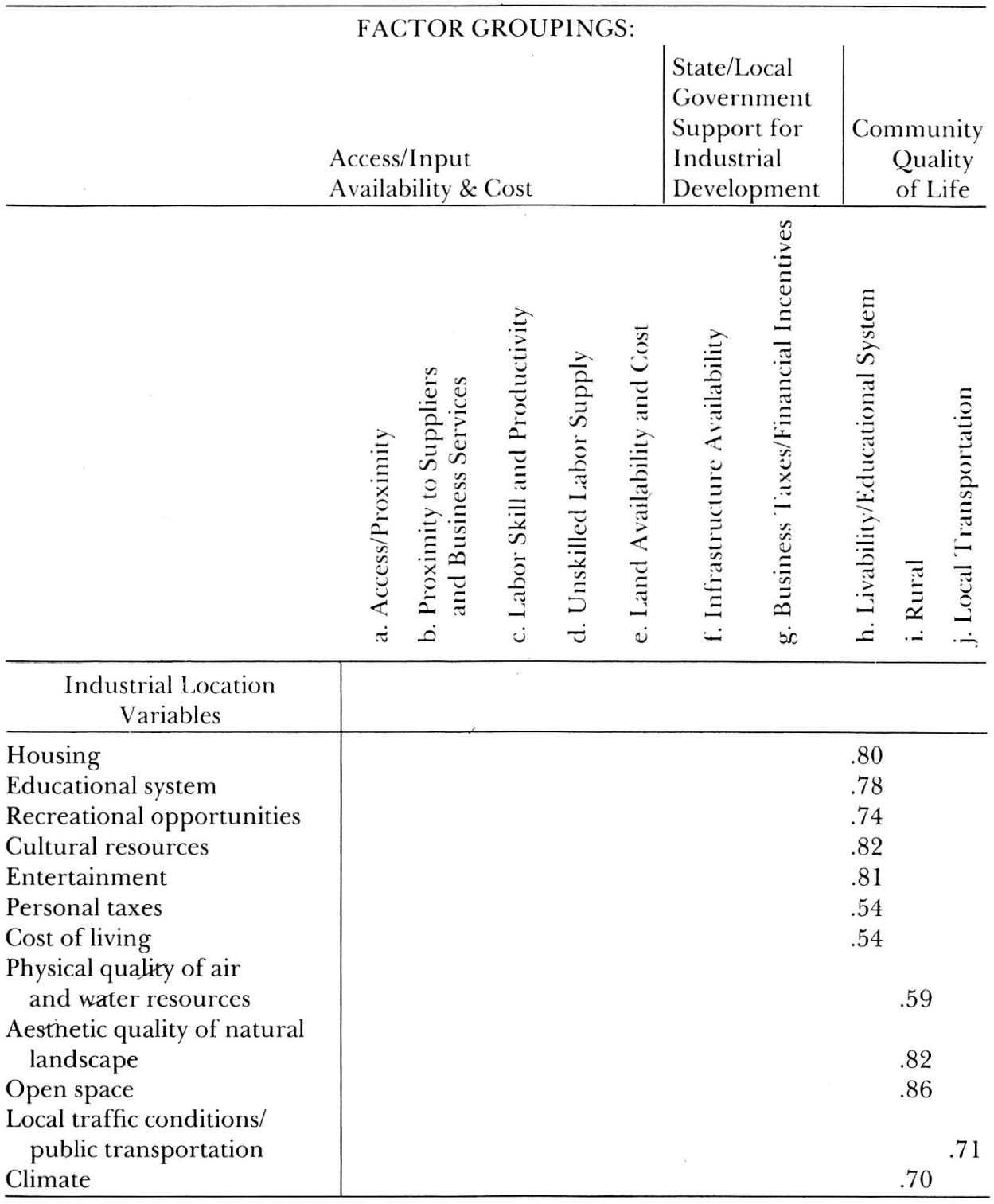

*Only factor loadings greater.than 0.50 are shown.

The pair-wise interactions and establishment type were not significant. These results guided the analysis of factor scores.

As the final step, average factor scores were plotted to see if these distinctive profiles for the three characteristics, examined separately and then in combination, could be interpreted in terms of the ten factors reflecting basic economic conditions, community quality of life and industrial development strategies in the southeast. 


\section{EMPIRICAL RESULTS}

The factors are clear and easy to interpret. Using the results of the varimax rotation, there are two factors which tap the access and proximity variables, three which cover the input availability and cost variables, two which focus on public sector actions that influence industrial development, and three community quality of life factors. Each factor is described more specifically in Table 3 which shows the variables with the highest factor loadings (all of which are positive). Recalling the logical groupings of variables shown in Table 1 , the derived factors show high consistency. The factors also appear to cover the major dimensions of the industrial location decision given two other findings. First, the executives were asked if there were any other locational factors not mentioned in the survey that they considered important. The executives identified very few additional variables. Second, when summary statistics for the 136 new establishments were examined for the 31 variables, variables related to access, input availability and cost which executives use to select regional location ranked the highest. Community quality of life variables which executives rely upon to select specific sites and variables used by public agencies to influence industrial development populated the middle and low range of the rankordering (Malizia, 1982).

By plotting and analyzing the standardized factor scores for different subsets of the sample, the differential influence of establishment type, employment size and industrial growth rate were analyzed. Branch plant executives rated availability and cost factors higher than the other factors, but the overall differences were not great. Compared to independent firms, it is fair to say that branch plant executives were more concerned about almost all of the locational factors. In other words, their factor scores were higher than those generated by independent firm executives. This result probably reflects the differences between these two groups of executives in the way that they approach the location decision (Carlton, 1979, Erickson and Leinbach, 1979, Moriarity, 1980, Schmenner, 1982, and Shapero, 1977). Executives are usually more systematic and rigorous in locating branch plants, both in identifying attractive regions and then in screening competing communities and sites. Independent firm executives engage in a less systematic process, considering only a few competing communities and/or sites. They usually have to start their business in the place where they have business connections and financial support. In other words, the business creation decision and the business location decision are collapsed for independent firms, with factors encouraging the start-up of the business dominating all other considerations. Compared to branch plant executives then, they should reveal a stronger orientation to local business conditions. Interestingly, the only factor more important to independent firm executives was the specific factor-proximity to suppliers and business services.

Contrasts between factor scores were heightened when the establishment's employment size and its industrial growth-rate characteristics were examined. Medium-sized establishments had scores more like large estab- 
lishments than small establishments for seven of the ten factors. The exceptions were understandable. The factor scores for large establishments were much higher for land availability/cost, infrastructure availability, and livability/education system and local transportation, factors most relevant to executives seeking a site for large-scale investments. It appears that executives locating large plants are quite concerned about what might be called the absorptive capacity of alternative communities and sites.

Overall, executives locating larger establishments rated all factors higher than executives locating small establishments except for the two access/ proximity factors and the rural factor. Like executives locating branch plants, those locating larger establishments appear to approach the location decision more comprehensively and systematically. They are concerned about labor skills/productivity, infrastructure availability, community quality of life factors, and business taxation/financial incentives. Conversely, like independent firm executives, those locating small establishments rate all factors lower except for the access and proximity factors (factors a and b).

FIGURE 1 Average Factor Scores of Establishments by Growth Rate

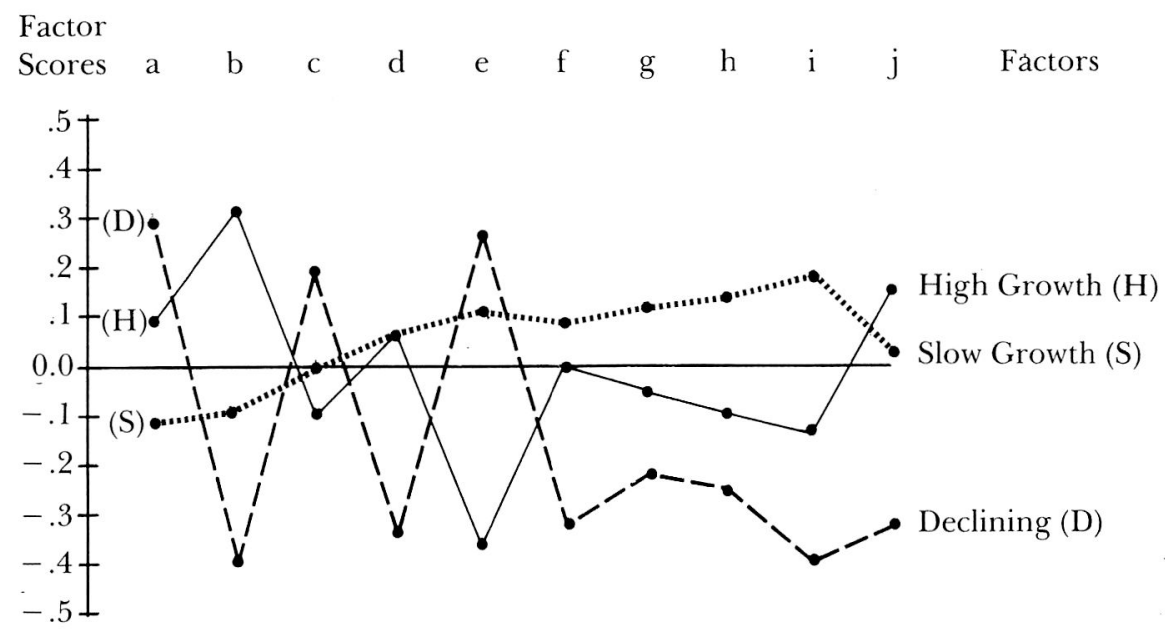

\section{FACTORS}

a. Access/Proximity

b. Proximity to Suppliers and Business Services

c. Labor Skill and Productivity

d. Unskilled Labor Supply

e. Land Availability and Cost

f. Infrastructure Availability

g. Business Taxes/Financial Incentives

h. Livability/Educational System

i. Rural

j. Local transportation 
Factor scores for establishments in nationally high-growth, slow-growth and declining industries are portrayed in Figure 1.2 Scores for 73 slowgrowth establishments are similar to branch plant and larger establishment profiles with the exception of their rural orientation. Except for access and proximity, the factor scores are greater than the averages for all establishments.

The profile for 21 declining manufacturers is striking in that access/ proximity, land availability/cost and labor skill/productivity are much more important than average while all other factors are much less important compared to all establishments. This may reveal a strong efficiency-inproduction-and-distribution orientation that would be expected of companies competing in nationally declining markets, for example, markets for standardized products. One surprise is the low score for unskilled labor supply-a critical input for manufacturers of standardized products. While it is possible that the declining industries represented in the sample were not producers of standardized products, a more plausible explanation is that the executives surveyed had already decided that the southeast had good interregional access and sufficient unskilled labor supply for the location of these capital-intensive facilities. This interpretation is implied by the sequential location decision-making process described above and by the finding that $95 \%$ of the executives surveyed, who had selected locations in North Carolina, South Carolina, or Virginia, said that they had only considered the southeastern region for their facilities.

The profile of factors scores for 42 high-growth industries are intriguing on several counts. First, proximity to supplies and business services is the only factor score significantly above the all establishment average. Second, the overall profile resembles the profiles for independent firms and for small establishments. From a causal perspective, however, it is unclear whether these executive preferences are more basic to those starting a business in a high-growth industry, to those starting a small business, or to those starting a new independent business. Because of the recent interest in small business development, it would be useful to sort out the relative importance of employment size, business type, industry growth rate, and other characteristics in future empirical research.

Since the general linear model identified one significant interaction effect for the combination of all three establishment characteristics, the 18 subsets of factor scores were analyzed. After eliminating eight subsets with less than five observations, most of the remaining comparisons proved to be either unrevealing or redundant with more general comparisons discussed above. The most interesting contrasts are given in Figures 2, 3, and 4 .

For both branch plants and independent firms, the 18 small, high-growth establishments may be compared to the 10 large, high-growth establishments as shown in Figure 2. Executives locating the 10 large establishments in high-growth industries rated livability/education, and, to a lesser extent, infrastructure availability and local transportation, much higher than any other factor compared to other subsets of executives. This may 
FIGURE 2

Average Factor Scores of Large and Small Establishments in High-Growth Industries

Factor

Scores

$\begin{array}{llllllllllll}\text { a } & \text { b } & \text { c } & \text { d } & \text { e } & f & g & \text { h } & \text { i } & \text { j } & \text { Factors }\end{array}$

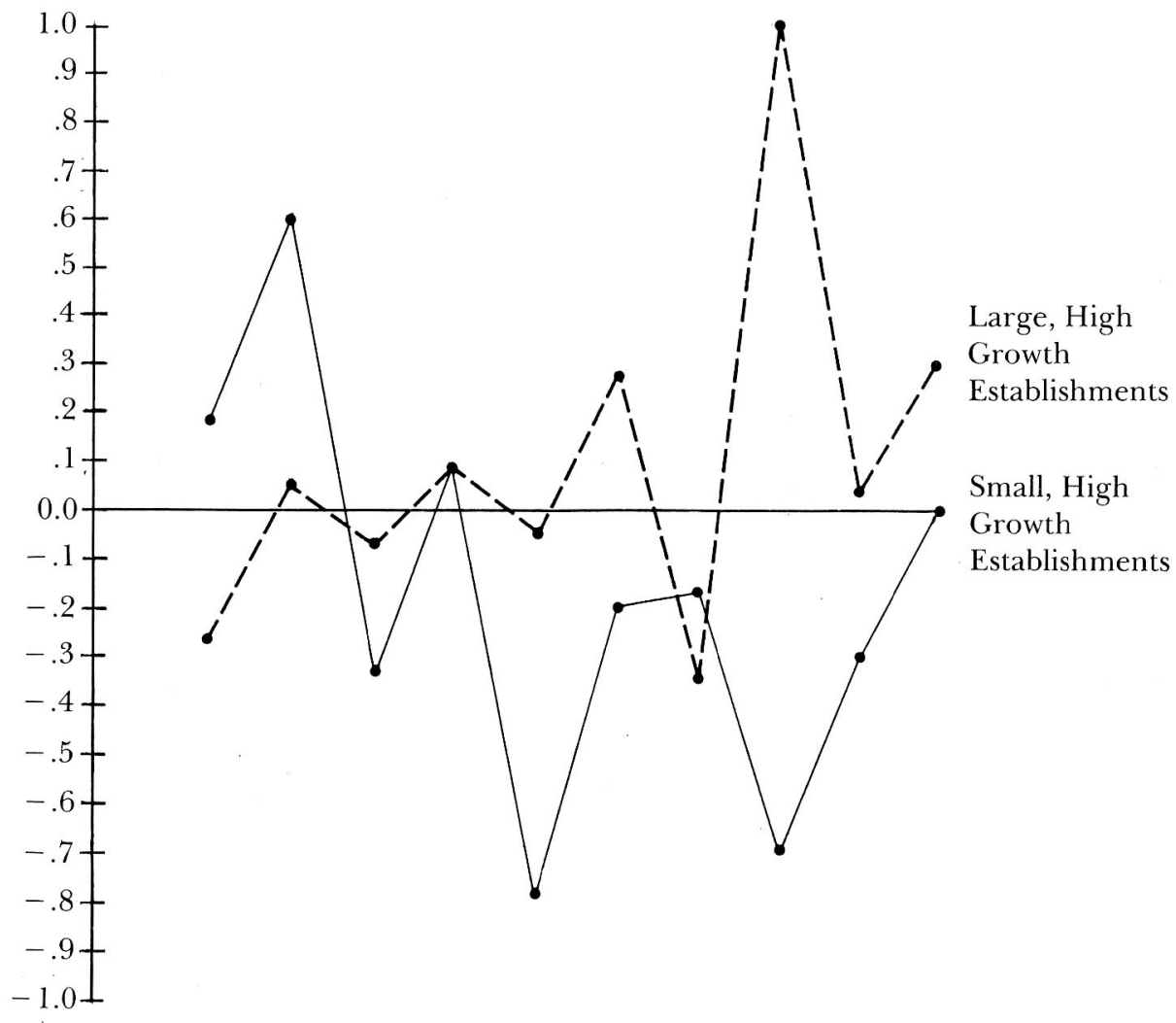

\section{FACTORS}

a. Access/Proximity

b. Proximity to Suppliers and Business Services

c. Labor Skill and Productivity

d. Unskilled Labor Supply

e. Land Availability and Cost

f. Infrastructure Availability

g. Business Taxes/Financial Incentives

h. Livability/Educational System

i. Rural

j. Local transportation 


\section{FIGURE 3}

Average Factor Scores of Small Branch and Independent Establishments in Slow-Growth Industries.

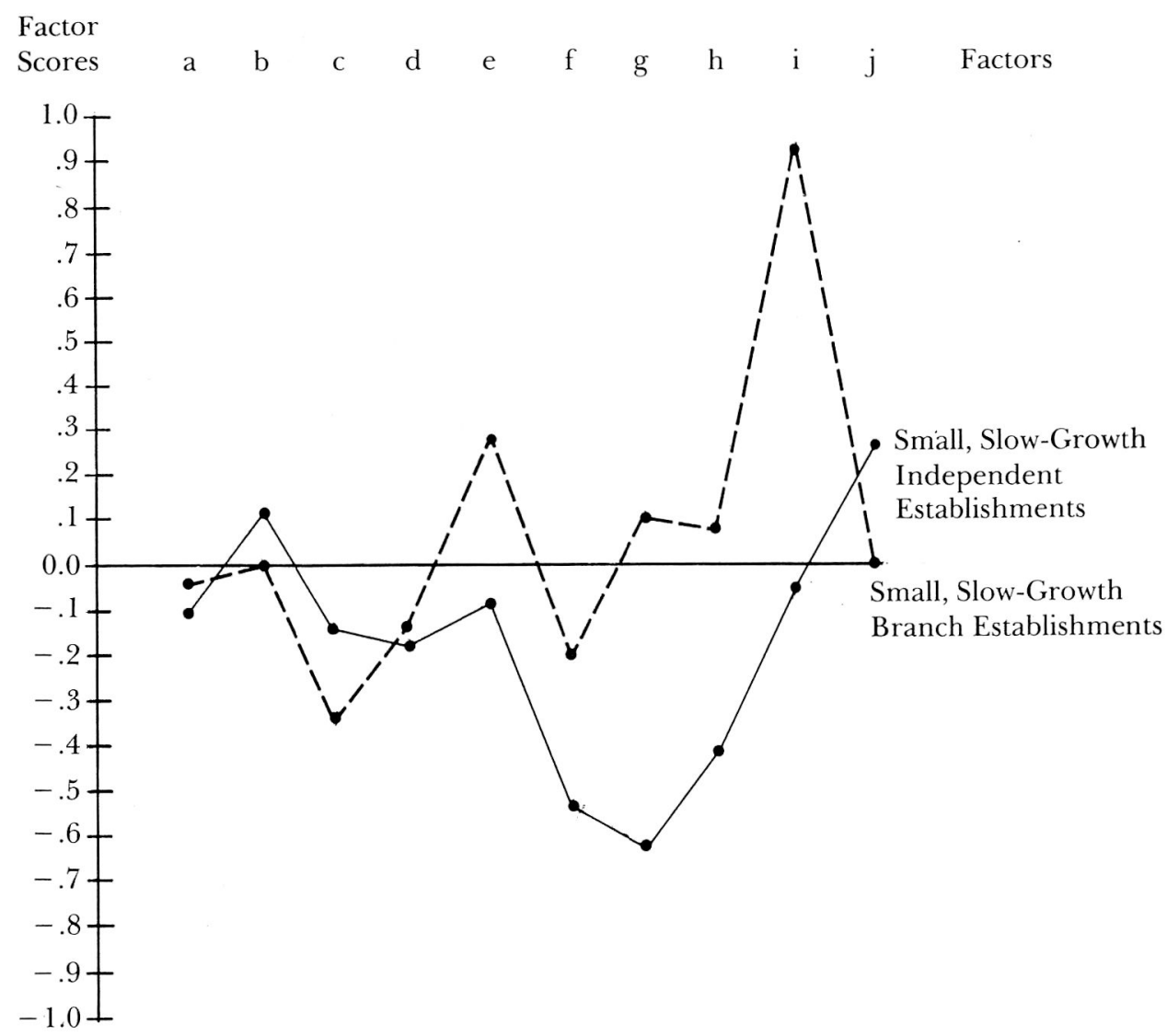

\section{FACTORS}
a. Access/Proximity
b. Proximity to Suppliers and Business Services
c. Labor Skill and Productivity
d. Unskilled Labor Supply
e. Land Availability and Cost
f. Infrastructure Availability
g. Business Taxes/Financial Incentives
h. Livability/Educational System
i. Rural
j. Local transportation

reflect the importance of holding on to key personnel (i.e. managers, technicians, scientists and engineers) who are thought to be concerned with community livability and quality of life. Executives locating the small, high- 
growth establishments emphasized the access and proximity factors. Thus, both groups of executives appear to share a strong local orientation that they express in quite different ways. In contrast to executives of large, highgrowth establishments interested in having key personnel satisfied with a location, executives of small, high-growth establishments need to remain in touch with their bankers, customers, suppliers, providers of business services, and possibly their local investors.

As shown in Figure 3, the executives locating the 19 small, slow-growth branch plants rated the rural and land availability/cost factors highest. Executives locating the 8 small, slow-growth independent firms scored only proximity to suppliers and business services and local transportation above average. Again, both groups of executives express their sensitivity to local economic conditions in quite different ways. Branch plant executives can focus narrowly on finding attractive sites offering low production costs because supportive services are provided by their headquarters (Fulton, 1974). Independent firm executives appear to forego certain production efficiencies in favor of locating in proximity to their business connections and contacts.

The comparison between the 23 large, slow-growth branch plants and the 8 small, high-growth independent firms highlights important influences of these establishment characteristics, as shown in Figure 4. Each profile almost forms a mirror image of the other. The most important differences are that executives locating the branch plants are much more concerned with land availability/cost and infrastructure availability while independent firm executives are more concerned with the access and proximity factors.

While these results are descriptive and not based on numerous observations, they do point to the conclusion that there are important differences among executives making locational decisions depending upon the characteristics of the establishment in question.

\section{SUMMARY AND CONCLUSIONS}

As expected, branch plants in slower growing or declining industries dominate the sample, and the profiles for branch plants, large establishments and slow-growth establishments, taken separately and in combination, are quite similar. Factors reflecting state and local government support for industrial development are most important to branch plants, large establishments and establishments in slow-growth industries (for example, review the profile for large, slow-growth branch plants in Figure 4). Unfortunately, these factors are relatively unimportant to independent firms, small establishments and establishments in high-growth industries, even less so when these characteristics are considered in combination. Thus, it appears that if southeastern industrial developers continue to pursue traditional strategies, they could realize continued success in attracting branchplants manufacturing standardized products but would not necessarily attract more dynamic, independent manufacturers, taken by many to be among the most desirable concerns. 


\section{FIGURE 4}

Average Factor Scores of Large, Slow-Growth Branches and Small, High-Growth Independents

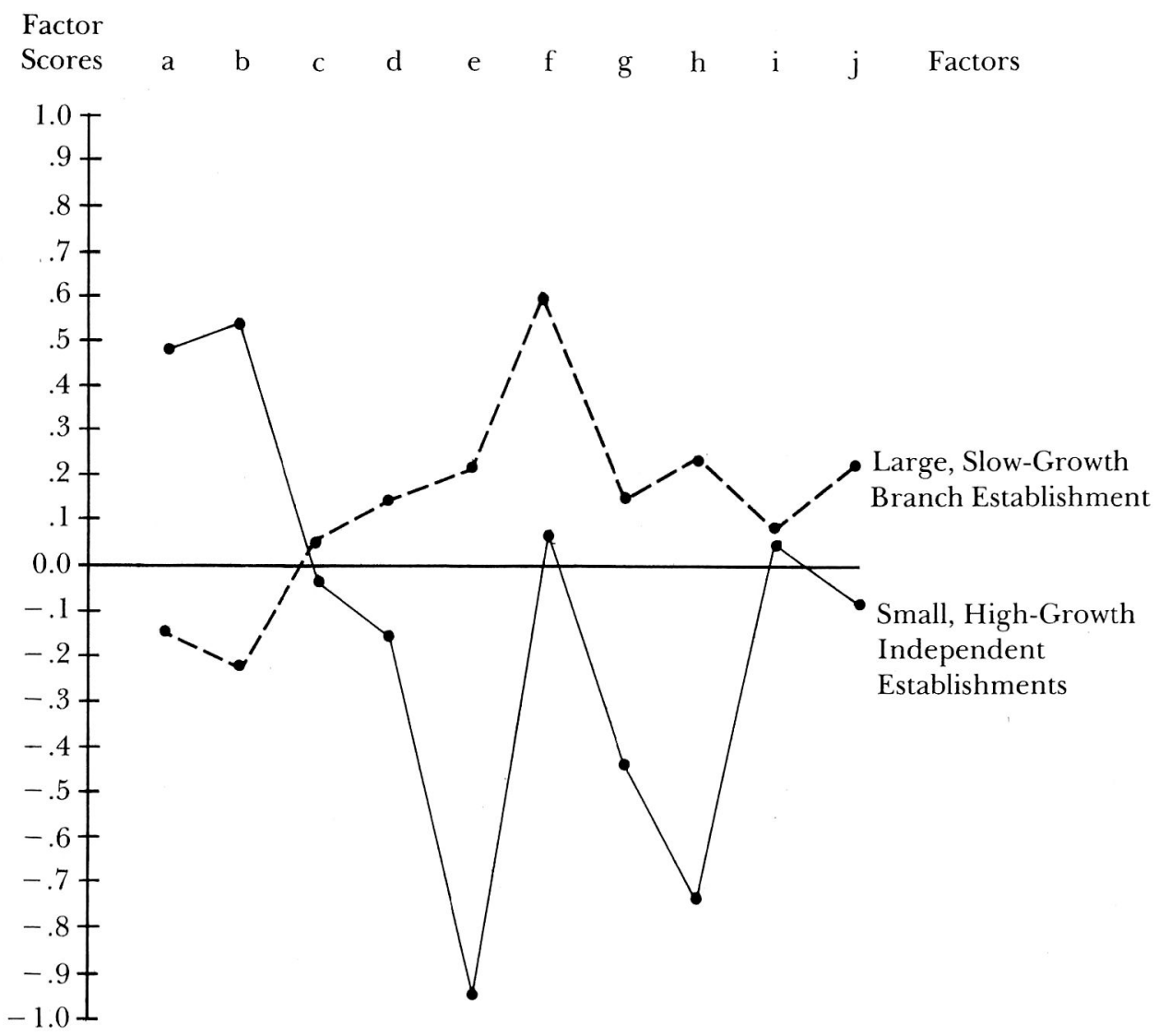

\section{FACTORS}
a. Access/Proximity
b. Proximity to Suppliers and Business Services
c. Labor Skill and Productivity
d. Unskilled Labor Supply
e. Land Availability and Cost
f. Infrastructure Availability
g. Business Taxes/Financial Incentives
h. Livability/Educational System
i. Rural
j. Local transportation

In this regard, it is important to remember that the decision to locate a given capital investment is not equivalent to the decision to make the capital investment in the first place. When national companies locate branch 
plants; the expansion decision is both separated from and prior to the location decision. But for independent firms, the start up decision and the location decision are essentially collapsed and simultaneous. Because the survey focused on the locational decision-making process, it failed to capture the basic factors that encourage executives to expand capacity or start a business in the first place. The results show that new independent firms are more likely to trade-off efficiency in production and distribution for the supportive business services available in a community, while branch plants can be located with little regard for considerations beyond the efficiency of production and distribution at the site.

The proximity-to-suppliers-and-business-services factor (specific factor b) comes closest to being a factor that may be critical in making the decision to start a new business. And that is the factor most important to independent firms, small establishments and establishments in high-growth industries, whether these characteristics are examined separately or in combination. Regional scientists have learned quite a bit about the industrial location process. Following some suggestive research (Thompson, 1968, Jacobs, 1969, pp. 86-96, and Shapero, 1977), we should try to better understand the process of new company formation in future regional studies.

FOOTNOTES

'The 1981 Industrial Outlook provided the information used to compute real growth rates at the four-digit SIC levels for each industry in the sample. At first, four growth-rate categories were defined in terms of average annual output levels from 1972 to 1978, as follows: highabove $8 \%$, moderate-between $5 \%$ and $8 \%$, slowbetween $-0.5 \%$ and $5 \%$, and decline-below $-0.5 \%$. At a later stage in the analysis, the first two categories were collapsed into one category.
Sample size constraints prevented an investigation by SIC, even at the two-digit level. Hekman, 1982 offers a recent analysis of the structure of manufacturing in the southeast.

${ }^{2}$ All scores are measured in standard deviation units. The horizontal line represents the average score profile for 136 establishments.
1. Barnet, R. J. and Müller, R. E. (1974) Global Reach. New York: Simon and Schuster.

2. Carlton, D. W. (1979) "Why New Firms Locate Where They Do," in W. C. Wheaton, ed. Interregional Movements and Regional Growth. Washington: Urban Institute.

3. Cromley, G. and Leinbach, R (1981) "The Pattern and Impact of the Filter-Down Process in Nonmetropolitan Kentucky," Economic Geography, 57 pp. 208224.

4. Czamanski, D. Z. (1981) "A Contribution to the Study of Industrial Location Decisions," Environment and Planning A, 13 pp. 29-42.

5. Erickson, A, and Leinbach, R. (1979) "Characteristics of Branch Plants Attracted to Nonmetropolitan Areas," R. E. Lonsdale and H. L. Seyler, eds. Nonmetropolitan Industrialization. Washington: V. H. Winston and Sons.

6. Fulton, M. (1974) "Industry's Viewpoint of Rural
Aréas," in L. R. Whiting, ed. Rural Industrialization. Ames: Iowa State Press.

7. Hansen, N. (1979) "The New International Division of Labor and Manufacturing Decentralization in the United States," The Review of Regional Studies, 9, pp. 1-11.

8. Haren, C. C. (1974) "Location of Industrial Production and Distribution," in L. R. Whiting, ed. Rural Industrialization. Ames: Iowa State Press.

9. Hekman, J. S. (1980) "The Product Cycle and New England Textiles," Quarterly Journal of Economics, 94, pp. 697-717.

10. the Southeast." (unpublished paper).

11. Hymer, S. (1972) "The Multi-National Corporation and the Law of Uneven Development," in J. N. Bagwati, ed. Economics and the World Order. London: McMillan Company. 
12. Jacobs, J. (1969) The Economy of Cities. New York: Random House.

13. Lonsdale, R. E. and Browning, E. (1971) "RuralUrban Locational Preferences of Southern Manufacturers," Annals: Association of American Geographers, 61, pp. 255-268.

14. Lonsdale, R. E. and Seyler, H. L., eds. (1979) Nonmetropolitan Industrialization. Washington: V. H. Winston \& Sons.

15. Malizia, E. (1982) "Making Communities Attractive to Business or Improving the Quality of Life." (unpublished paper).

16 and Reid, D. (1976) "Perspectives and Strategies for U. S. Regional Development," Growth and Change, 7, pp. 41-47.

17. Moriarity, B. M. (1980) Industrial Location and Community Development. Chapel Hill: UNC Press.

18. Norton, R. D. and Rees, J. (1979) "The Product Cycle and the Spatial Decentralization of American Manufacturing," Regional Studies, 13, pp. 141-151.

19. Schmenner, R. W. (1982) Making Business Location Decisions. Englewood Cliffs, N. J.: Prentice Hall.
20. Shapero, A. (1977) "The Role of Entrepreneurship in Economic Development at the Less-Than-National Level." Washington: Economic Development Administration, U. S. Department of Commerce.

21. Thompson, W. R. (1968) "Internal and External Factors in the Development of Urban Economies," in H. S. Perloff and L. Wingo, Jr., eds. Issues in Urban Economics. Baltimore: Johns Hopkins Press.

22. Till, T. (1973) "The Extent of Industrialization in Southern Nonmetro Labor Markets in the 1960s," Journal of Regional Science, 13, pp. 453-461.

23. Vaughan, R. J. (1977) The Urban Impacts of Federal Policies: Vol 2, Economic Development. Santa Monica: RAND.

24. Vernon, R. (1966) "International Investment and International Trade in the Product Cycle," Quarterly Journal of Economics, 80, pp. 190-207.

25. Weinstein, B. L. and Firestein, R. E. (1978) Regional Growth and Decline in the United States. New York: Praeger Publishers. 